\title{
Simultaneous removal of hydrogen sulfide and toluene in a bioreactor: Performance and characteristics of microbial community
}

\author{
Min Gao, Lin Li, Junxin Liu* \\ Research Center for Eco-Environmental Sciences, Chinese Academy of Sciences, Beijing 100085, China. E-mail: jxliu@ rcees.ac.cn
}

Received 07 April 2010; revised 22 May 2010; accepted 26 May 2010

\begin{abstract}
We investigated the correlation between performance and the bacteria community composition by $\mathrm{H}_{2} \mathrm{~S}$ and toluene co-treatment. Operation of the bioreactor was divided into four stages, in which the inlet concentration of toluene and $\mathrm{H}_{2} \mathrm{~S}$ were gradually increased. In Stage I, toluene was the sole target compound with an average removal efficiency of $86.49 \%$. After adding $\mathrm{H}_{2} \mathrm{~S}$ in Stage II, removal efficiency of toluene decreased immediately and recovered gradually to $85.96 \%$. When the inlet concentration of toluene and $\mathrm{H}_{2} \mathrm{~S}$ was increased in Stage III and Stage IV, respectively, the average removal efficiency for toluene increased continuously from $86.31 \%$ to $87.24 \%$. The elimination capacities of toluene increased with increasing inlet loading rates of toluene and $\mathrm{H}_{2} \mathrm{~S}$. Results of the PCR-DGGE analysis showed a turnover growth and decline of the microbial populations in the bioreactor. In Stage I, the dominant toluene-degrading bacteria mainly contained Pseudomonas sp. strain PS+ and Hydrogenophaga sp. In Stage IV, however, the dominant toluene-degrading bacteria was aciduric bacteria (Clostridium populeti). The dominant microbial community in the bioreactor enhanced the elimination capacity of toluene, and adding $\mathrm{H}_{2} \mathrm{~S}$ changed the environment of microbial growth, thus resulted in an evolution of dominant microorganisms. Analyses of microbial community and their activities provides valuable information to efficiently enhance simultaneous removal of toluene and $\mathrm{H}_{2} \mathrm{~S}$ in the bioreactor.
\end{abstract}

Key words: off-gas treatment; bacterial community; hydrogen sulfate; toluene

DOI: $10.1016 / \mathrm{S} 1001-0742(10) 60416-0$

Citation: Gao M, Li L, Liu J X, 2011. Simultaneous removal of hydrogen sulfide and toluene in a bioreactor: Performance and characteristics of microbial community. Journal of Environmental Sciences, 23(3): 353-359

\section{Introduction}

Air pollution is a growing environmental issue and global policies aim to reduce the emission of volatile and gaseous compounds. Volatile organic compounds (VOCs) and odorous compounds have gained much attention because of their direct impact on human health and the environment (Jenkin et al., 2008). Air pollution emissions from publicly owned treatment works (POTWs) are a mixture of VOCs such as toluene and odorous compounds, for example hydrogen sulfide $\left(\mathrm{H}_{2} \mathrm{~S}\right)$ (Liang et al., 2007). Many studies have focused on the elimination of either toluene or $\mathrm{H}_{2} \mathrm{~S}$ from off-gases, and bioreactors are universally used because of their simplicity and cost effectiveness (Dorado et al., 2008; Duan et al., 2006; Groenestijn and Kraakman, 2005; Morgan-Sagastume and Noyola, 2006; Pedersen and Arvin, 1997). Various physicochemical parameters and characteristics of microbial communities have been investigated to optimize bioreactor performance (Auria et al., 2000; Morales et al., 2003).

Investigating performance and the microbial community in treating toluene vapor in a biofilter revealed that bacteria

\footnotetext{
* Corresponding author. E-mail: jxliu@ rcees.ac.cn
}

numbers increased while moulds and actinomyces decreased with increasing initial moisture content of packing material (Sun et al., 2002). Specific 16S rRNA probes were used to analyze the toluene-degrading population in a laboratory-scale biofilter for waste gas treatment. Results indicated that $P$. putida was responsible for a significant part $(65 \%)$ of the toluene degraded by the entire community (Møller et al., 1996). Sercu et al. (2006) studied the microbial composition of the most active and abundant bacteria in $\mathrm{H}_{2} \mathrm{~S}$-removing biofilter by denaturing gradient gel electrophoresis (DGGE). Dominant ribotypes were sequenced and identified as the possible key players in $\mathrm{H}_{2} \mathrm{~S}$ removal.

Recent research has found that toluene and $\mathrm{H}_{2} \mathrm{~S}$ can be removed simultaneously in a single bioreactor. Cox and Deshusses (2002) investigated co-treatment effects of $\mathrm{H}_{2} \mathrm{~S}$ and toluene in a biotrickling filter, which indicated that $\mathrm{H}_{2} \mathrm{~S}$ did not affect toluene degradation under either neutral or acidic conditions. Liang et al. (2007) used biological activated carbon as a biofilter packing material to treat off-gas with toluene and $\mathrm{H}_{2} \mathrm{~S}$, and demonstrated effective simultaneous treatment of toluene and $\mathrm{H}_{2} \mathrm{~S}$ at low $\mathrm{pH}$. However, $\mathrm{H}_{2} \mathrm{~S}$ is usually oxidized by Thiobacillus species, 
which exhibit optimum activity at acidic $\mathrm{pH}$ (Islander et al. 1991), and toluene-degrading bacteria such as $P$. putida, which exhibit optimum activity at neutral-pH. Therefore, although co-treatment of toluene and $\mathrm{H}_{2} \mathrm{~S}$ in a bioreactor has been achieved, little is known on the characteristics of microbial community for simultaneous removal of toluene and $\mathrm{H}_{2} \mathrm{~S}$. The aim of this study was to investigate the correlation between bioreactor performance and community structure by polymerase chain reaction (PCR)-DGGE.

\section{Materials and methods}

\subsection{Experimental setup and operational conditions}

This study was carried out in a laboratory-scale bioreactor made of a Plexiglas column with $0.32 \mathrm{~m}$ in height and $0.15 \mathrm{~m}$ in diameter (Fig. 1). Polyurethane foam 0.045 $\mathrm{m}$ thick was packed in the bioreactor as a carrier of microbial growth. Two sampling ports for measuring inlet or outlet gas concentrations were set at the bottom and top of the carrier, respectively. Two containers, one filled with toluene and one with $\mathrm{H}_{2} \mathrm{SO}_{4}$, were placed at the bottom of the bioreactor for $\mathrm{H}_{2} \mathrm{~S}$ generation. The inlet $\mathrm{H}_{2} \mathrm{~S}$ concentration was controlled by adjusting the dripping rate of $\mathrm{Na}_{2} \mathrm{~S}$ solution using a peristaltic pump, and the inlet toluene concentration was varied by changing the container surface. The bioreactor operated for 84 days, which was divided into four stages and a step increase in inlet toluene and $\mathrm{H}_{2} \mathrm{~S}$ concentrations was implemented.

Stage I (day 1-32): operating term was 32 days, toluene was the only pollutant in the inlet, and its concentration was $2.7-3.0 \mathrm{~g} / \mathrm{m}^{3}$.

Stage II (day 33-51): operating term was 19 days, the inlet concentration of toluene was increased to 3.0-3.4 $\mathrm{g} / \mathrm{m}^{3}$, and $\mathrm{H}_{2} \mathrm{~S}$ of $0.05-0.07 \mathrm{~g} / \mathrm{m}^{3}$ was added into the inlet gas.

Stage III (day 52-day 63): operating term was 12 days, the inlet concentration of toluene was continuously increased to $4.0-4.2 \mathrm{~g} / \mathrm{m}^{3}$, and the concentration of $\mathrm{H}_{2} \mathrm{~S}$ was increased to $0.16-0.20 \mathrm{~g} / \mathrm{m}^{3}$.

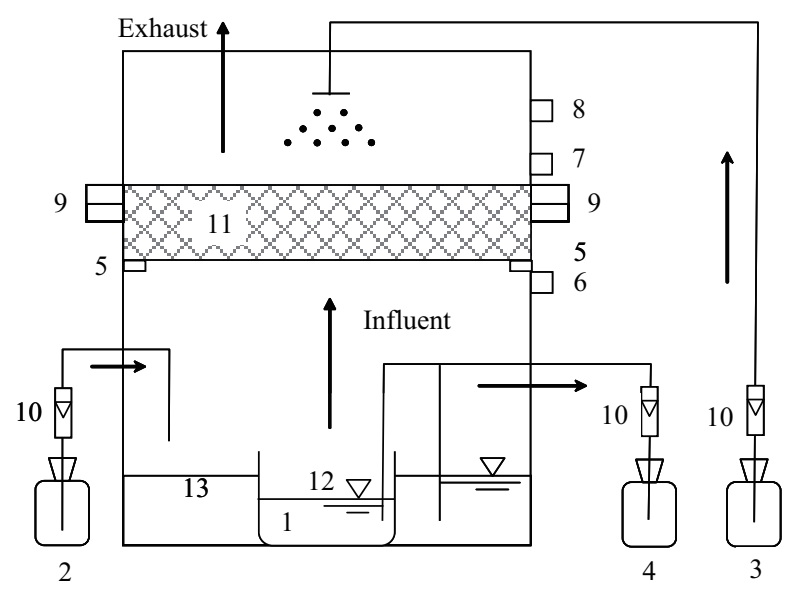

Fig. 1 Schematic diagram of the bioreactor. (1) liquid toluene; (2) sodium sulfide solution; (3) nutrient tank; (4) collection of waste liquid; (5) the support for carrier; (6), (7), (8) sampling port; (9) flange; (10) peristaltic pump; (11) carrier; (12) container for liquid toluene; (13) container for sulfate solution.
Stage IV (day 64-day 84): operating term was 21 days, the inlet concentration of toluene was retained in 3.9-4.1 $\mathrm{g} / \mathrm{m}^{3}$, and the concentration of $\mathrm{H}_{2} \mathrm{~S}$ was increased to $0.35-$ $0.38 \mathrm{~g} / \mathrm{m}^{3}$.

To quickly start the bioreactor, the microorganism from a biofilter treated xylene off-gas as the inoculum was seeded on polyurethane foam carrier. The nutrient solution was regularly sprayed on the surface of the carrier to maintain microorganism activity. The nutrient solution had the

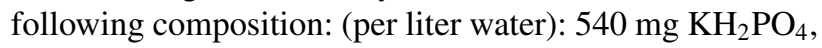
$1380 \mathrm{mg} \mathrm{K} \mathrm{HPO}_{4} \cdot 3 \mathrm{H}_{2} \mathrm{O}, 1000 \mathrm{mg} \mathrm{NaCl}, 25 \mathrm{mg} \mathrm{MgSO}$, $20 \mathrm{mg} \mathrm{CaCl}_{2}, 5 \mathrm{mg} \mathrm{FeSO} \cdot 4 \mathrm{H}_{2} \mathrm{O}, 2 \mathrm{mg} \mathrm{MnSO}_{4} \cdot 7 \mathrm{H}_{2} \mathrm{O}$, and $1 \mathrm{~mL} / \mathrm{L}$ trace element solution. The solution $\mathrm{pH}$ was adjusted to 7.0 by adding $0.1 \mathrm{~mol} / \mathrm{L}$ of $\mathrm{NaOH}$ or 0.1 $\mathrm{mol} / \mathrm{L}$ of $\mathrm{HCl}$. The bioreactor was continuously operated at ambient temperature between 18 and $30^{\circ} \mathrm{C}$.

\subsection{Analytical methods}

\subsubsection{Gas and liquid samples}

Toluene gas concentration was analyzed by a chromatography unit (Agilent GC-6890, USA) equipped with a flame ionization detector (FID) and DB-FFAP capillary column $(30 \mathrm{~m} \times 0.32 \mathrm{~mm} \times 0.25 \mu \mathrm{m}$ Hewlett Packard, USA). Nitrogen with a flow rate of $60 \mathrm{~mL} / \mathrm{min}$ was used as the carrier gas. The concentration of $\mathrm{CO}_{2}$ were determined by a gas chromatography (GC) unit (Agilent $6890 \mathrm{~N}$, USA) equipped with a 2-m stainless-steel column packed with Porapak $\mathrm{T}$ and thermal conductivity detector (TCD). Helium with a flow rate of $10 \mathrm{~mL} / \mathrm{min}$ was used as the carrier gas. The GC oven temperature was set to $60^{\circ} \mathrm{C}$. The injection and detector temperatures were set at 100 and $200^{\circ} \mathrm{C}$, respectively. Column temperature for acetic acid analysis was held at $70^{\circ} \mathrm{C}$ for $1 \mathrm{~min}$ and then increased at a rate of $20^{\circ} \mathrm{C} / \mathrm{min}$ to $180^{\circ} \mathrm{C}$. The injector and detector were maintained at 240 and $260^{\circ} \mathrm{C}$, respectively. Nitrogen was employed as the carrier gas at a flow rate of $2.6 \mathrm{~mL} / \mathrm{min}$, which remained constant via electronic pressure control. Concentrations of $\mathrm{SO}_{3}{ }^{2-}$ and $\mathrm{SO}_{4}{ }^{2-}$ were determined according to the standard method (APHA, 1998). The $\mathrm{pH}$ value was measured by a $\mathrm{pH}$ meter ( $\mathrm{pH}-10$ Satorius, Germany).

\subsubsection{Microbiological analysis}

DNA extraction was conducted following manufacturers instruction in the test kit (Omega, USA).

Polymerase chain reaction (PCR) amplification

Chains 357f (5' - CGCCCGCCGCGCGCGGCGGGCGGGGCGGGGGCACGGGGGGCCTACGGGAGGCAGCAG-3') and 518r (5'-ATTACCGCGGCTGCTGG-3') were used to amplify the segment of $16 \mathrm{~S}$ rDNA (Sanchez et al., 2007). The GC clamp was added to the forward primers to facilitate the DGGE. The PCR amplification reaction was performed using an MJ Research PTC-200 Peltier thermal cycler (Bio-Rad, USA) at a final volume of $50 \mu \mathrm{L}$. The reaction mixture contained $20 \mathrm{pmol}$ of primers, $20 \mu \mathrm{mol}$ of each dNTPs, $5 \mu \mathrm{L}$ of $10 \times$ buffer (TaKaRa, China), and 1.25 units of Taq DNA polymerase (TaKaRa, China). The temperature cycling conditions were $94^{\circ} \mathrm{C}$ for $3 \mathrm{~min}$, followed by 31 cycles of $94^{\circ} \mathrm{C}$ for $30 \mathrm{sec}, 55^{\circ} \mathrm{C}$ for 
$30 \mathrm{sec}, 72^{\circ} \mathrm{C}$ for $1 \mathrm{~min}$, and a final extension at $72^{\circ} \mathrm{C}$ for $10 \mathrm{~min}$. Approximately $5 \mu \mathrm{L}$ aliquot of the PCR product was separated on a $0.8 \%(W / V)$ agarose gel at $100 \mathrm{~V}$ for 30 min to verify amplification prior to DGGE. The PCR product generated from each sample was separated on an $8 \%$ acrylamide gel with a linear denaturant gradient increasing from $30 \%$ to $60 \%$ using the Bio-Rad D-GENE System (USA). The DGGE was performed using $30 \mu \mathrm{L}$ of the PCR product in $1 \times$ TAE buffer at $60^{\circ} \mathrm{C}$ and 100 $\mathrm{V}$ for $750 \mathrm{~min}$. The resulting gel was visualized with Gel Red (Biotium USA). The digital images were captured by the Fluor-S MultiImager (Bio-Rad, USA). The relative band densities of DGGE bands (Qty) were calculated by Quantity One Software (Bio-Rad, USA).

Sequence analysis of bands excised from DGGE

Prominent DGGE bands were selected and used for excision. The reamplified products were purified by a Gel Recovery Purification Kit (Watson Biotechnologies Inc, Shanghai, China) and cloned by the pMD18-T plasmid vector system (Ta-KaRa, China) according to the manufacturer's instructions. The cloned PCR fragments were sequenced by an ABI-Prism model 3730 automatic sequencer (PerkinElmer, USA). Gene sequence chromatographs were analyzed using the CHROMAS LITE software package version 2.01 (http://www.technelysium.com.au/chromas_lite.html) and the resulting sequences' closest relatives were identified by NCBI nucleotide-nucleotide BLAST (http://www.ncbi.nlm.nih.gov/). All 16S rRNA gene sequences were deposited in the database under the accession numbers FJ873130-FJ873147.

\subsubsection{Statistical analysis}

Bacterial diversity was estimated from the intensity and number of bands using the Shannon index $(H)$ described by Ding et al. (2008).

$H=-\sum\left(n_{i} / N\right) \ln \left(n_{i} / N\right)$

where, $n_{i}$ is the peak height of each band, $i$ is the number of bands in each DGGE gel profile, and $N$ is the sum of the peak heights in a given DGGE gel profile.

\subsection{Evaluation method}

As toluene was a saturated liquid, the vaporization velocity $(Q)$ and vaporization concentration $(C)$ could be controlled by adjusting volatile surface. As air movement and ambient temperature remain unchanged, $C$ and $Q$ tend to be constant when the volatile surface of liquid is constant. The performance of the bioreactor was evaluated by a series of parameters, such as reduce efficiency (RE, $\%$ ); inlet load (IL, $\mathrm{g} /\left(\mathrm{m}^{3} \cdot \mathrm{hr}\right)$ ); empty bed residence time (EBRT, sec), and elimination capacity $\left(\mathrm{EC}, \mathrm{g} /\left(\mathrm{m}^{3} \cdot \mathrm{hr}\right)\right)$. The definitions for these parameters are as follows:

$Q=\frac{V}{T}$

$\mathrm{RE}=\left(\frac{C_{\text {in }}-C_{\text {out }}}{C_{\text {in }}}\right) \times 100 \%$

$\mathrm{EC}=Q \times \frac{C_{\text {in }}-C_{\text {out }}}{V_{\mathrm{c}}}$

$\mathrm{IL}=\frac{Q \times C_{\text {in }}}{V_{\mathrm{c}}}$

$\mathrm{EBRT}=\frac{V_{\mathrm{c}}}{Q}$

$M=\frac{C_{\mathrm{m}}}{C_{\mathrm{t}}} \times 100 \%$

where, $Q\left(\mathrm{~m}^{3} / \mathrm{hr}\right)$ is the vaporization velocity of toluene gas; $V\left(\mathrm{~m}^{3}\right)$ is the volume of toluene saturated liquid; $V_{\mathrm{c}}$ $\left(\mathrm{m}^{3}\right)$ is the volume of the carrier; $T(\mathrm{sec})$ is the vaporization time of saturated liquid toluene totally evaporated to gas state; $C_{\text {in }}\left(\mathrm{g} / \mathrm{m}^{3}\right)$ is the toluene concentration at down surface of the carrier; $C_{\text {out }}\left(\mathrm{g} / \mathrm{m}^{3}\right)$ is the toluene concentration at up surface of the carrier; $M$ is the $\mathrm{CO}_{2}$ conversion rate of toluene; $C_{\mathrm{m}}\left(\mathrm{g} / \mathrm{m}^{3}\right)$ is the measured concentration of $\mathrm{CO}_{2}$; and $C_{\mathrm{t}}\left(\mathrm{g} / \mathrm{m}^{3}\right)$ is the theoretical concentration of $\mathrm{CO}_{2}$.

\section{Results and discussion}

\subsection{Performance of the bioreactor}

The steady operation of the bioreactor started quickly due to the adaptation of toluene-degrading bacteria initially inoculated into the bioreactor. Figure 2 shows the performance of the bioreactor, including the removal efficiencies of toluene and $\mathrm{H}_{2} \mathrm{~S}$ under different inlet concentrations of toluene and $\mathrm{H}_{2} \mathrm{~S}$. The average removal efficiencies of toluene and $\mathrm{H}_{2} \mathrm{~S}$ in each operational stage are listed in Table 1. In Stage I, toluene was the sole pollutant. Approximately $80 \%$ of toluene could be removed within one day of toluene biodegradation. Toluene removal increased significantly with extension of operational time and reached a steady state after 10 days. The average removal efficiency of toluene was $86.49 \%$ in Stage I. However, the removal efficiency of toluene decreased immediately from $87.78 \%$ to $82.10 \%$ after adding $\mathrm{H}_{2} \mathrm{~S}$. Twenty days later, it began to rebound and recovered gradually to $85.96 \%$. Toluene removal was enhanced even though the concentration of toluene and $\mathrm{H}_{2} \mathrm{~S}$ increased. The average removal efficien-

Table 1 Removal efficiency and products of toluene and $\mathrm{H}_{2} \mathrm{~S}$

\begin{tabular}{|c|c|c|c|c|c|}
\hline & Time & Stage I & Stage II & Stage III & Stage IV \\
\hline \multirow[t]{3}{*}{ Toluene removal } & Inlet concentration $\left(\mathrm{g} / \mathrm{m}^{3}\right)$ & $2.7-3.0$ & $3.0-3.4$ & $4.0-4.2$ & $3.9-4.1$ \\
\hline & Average removal efficiency (\%) & 86.49 & 84.81 & 86.31 & 87.24 \\
\hline & Average acetic acid (mg/L) & 84.62 & 145.65 & 114.82 & 109.64 \\
\hline \multirow[t]{3}{*}{$\mathrm{H}_{2} \mathrm{~S}$ removal } & Average sulfate $(\mathrm{mg} / \mathrm{L})$ & - & 1380 & 1670 & 3680 \\
\hline & Inlet concentration $\left(\mathrm{g} / \mathrm{m}^{3}\right)$ & 0 & $0.05-0.07$ & $0.16-0.20$ & $0.35-0.38$ \\
\hline & Average removal efficiency (\%) & - & 93.62 & 91.85 & 91.84 \\
\hline
\end{tabular}




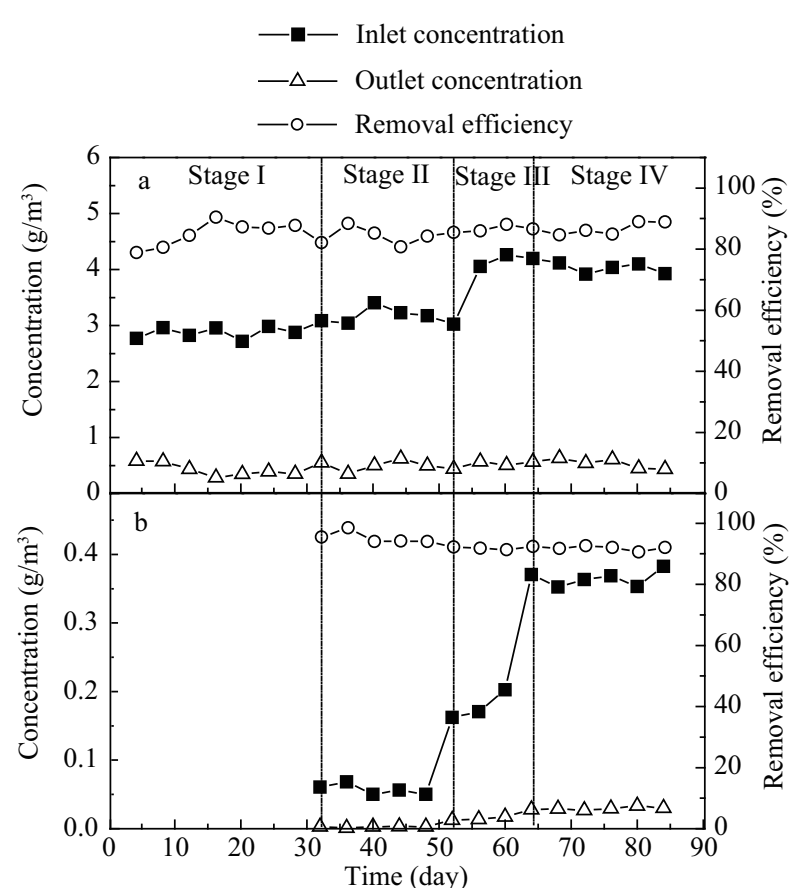

Fig. 2 Profiles of toluene (a) and $\mathrm{H}_{2} \mathrm{~S}$ (b) removal efficiencies and concentrations in the inlet and outlet of the bioreactor.

cies of toluene were $86.31 \%$ (Stage III) and $87.24 \%$ (Stage IV). The $\mathrm{H}_{2} \mathrm{~S}$ removal was steady during this operation, and average removal efficiencies in Stage II, III and IV of operation were $93.62 \%, 91.85 \%$ and $91.84 \%$, respectively.

Elimination capacity is an important parameter to evaluate bioreactor performance. The increase in toluene and $\mathrm{H}_{2} \mathrm{~S}$ concentrations resulted in an increase in inlet loading rate of the bioreactor. Results in Fig. 3 show that the elimination capacity of the bioreactor for toluene removal increased with increasing inlet loading rates. In Stage I, the average inlet loading rate of toluene was $20.30 \mathrm{~g} /\left(\mathrm{m}^{3} \cdot \mathrm{hr}\right)$, and average elimination capacity of toluene was 17.16 $\mathrm{g} /\left(\mathrm{m}^{3} \cdot \mathrm{hr}\right)$. In Stage IV, the average inlet loading rate of toluene and $\mathrm{H}_{2} \mathrm{~S}$ increased to 47.01 and $4.30 \mathrm{~g} /\left(\mathrm{m}^{3} \cdot \mathrm{hr}\right)$, respectively, and average elimination capacity of toluene and $\mathrm{H}_{2} \mathrm{~S}$ achieved 41.73 and $3.91 \mathrm{~g} /\left(\mathrm{m}^{3} \cdot \mathrm{hr}\right)$, respectively. The bioreactor removed toluene and $\mathrm{H}_{2} \mathrm{~S}$ simultaneously with a high elimination capacity.

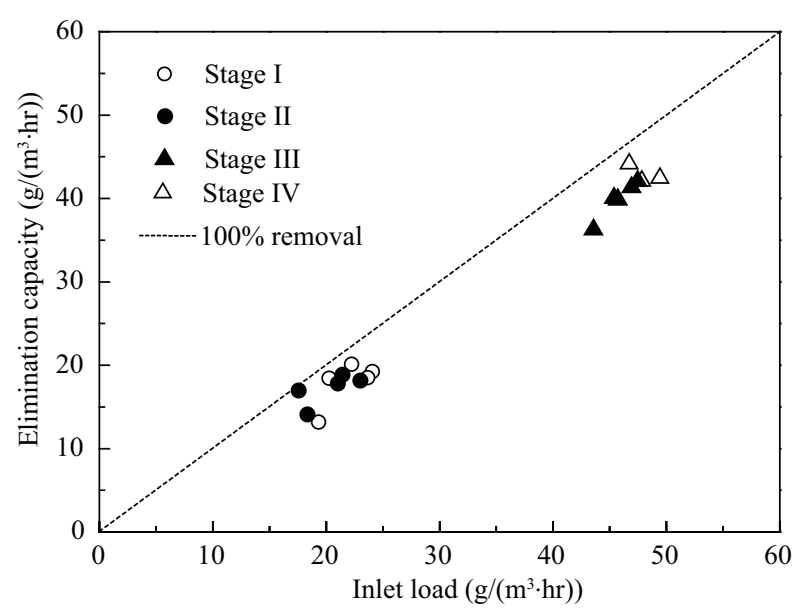

Fig. 3 Removal capacity of toluene at different stages.

\subsection{Characteristics of products}

Biodegradation of toluene produces $\mathrm{CO}_{2}$, water, and metabolites, while bio-oxidation of $\mathrm{H}_{2} \mathrm{~S}$ produces sulfate. Measuring the products can provide insight into the performance of the bioreactor. The $\mathrm{CO}_{2}$ conversion rate $(M)$ can be used to estimate biodegradation degree of toluene. Theoretically, $7 \mathrm{~mol}$ of $\mathrm{CO}_{2}$ will be obtained when $1 \mathrm{~mol}$ of toluene is degraded completely (Reaction (8)).

$\mathrm{C}_{7} \mathrm{H}_{8}+9 \mathrm{O}_{2}=7 \mathrm{CO}_{2}+4 \mathrm{H}_{2} \mathrm{O}$

Besides $\mathrm{CO}_{2}$, the products of toluene degradation include metabolites and biomass. In this study, acetic acid was the main metabolite for toluene degradation. The average concentrations of acetic acid and sulfate are listed in Table 1.

Figure 4 describes $M$ variation with the ratio of $\mathrm{H}_{2} \mathrm{~S}$ and toluene concentration $\left(R_{\mathrm{H} / \mathrm{T}}\right)$ in each stage. In most of the running time, $M$ remained at $35 \%$. After adding $\mathrm{H}_{2} \mathrm{~S}$, however, $M$ decreased to $30 \%$ before gradually recovering again to $35 \%$. The results in Fig. 4 show no evident correlation between the change of $M$ and $R_{\mathrm{H} / \mathrm{T}}$. However, $M$ correlated with the change of acetic acid. In Stage I, the average concentration of acetic acid was $84.62 \mathrm{mg} / \mathrm{L}$. In Stage II, the concentration of acetic acid increased to $145.65 \mathrm{mg} / \mathrm{L}$ with decreasing $M$. In Stage III and IV, the concentration of acetic acid decreased to 114.82 and $109.64 \mathrm{mg} / \mathrm{L}$, respectively, with increasing $M$ (Table 1).

The product of $\mathrm{H}_{2} \mathrm{~S}$ was sulfate during aerobic biodegradation. The concentration of sulfate increased from 1380 $\mathrm{mg} / \mathrm{L}$ (in Stage II) to $3680 \mathrm{mg} / \mathrm{L}$ (in Stage IV) with increasing $\mathrm{H}_{2} \mathrm{~S}$ inlet concentration (Table 1). In addition, the $\mathrm{pH}$ value of Stage I was 6.45. After adding $\mathrm{H}_{2} \mathrm{~S}$, the $\mathrm{pH}$ value of Stage II, III and IV were 2.85, 2.92 and 2.69, respectively, in the bioreactor.

\subsection{Bacterial community composition in the bioreactor}

\subsubsection{Bacterial diversity and community composition}

Traditional plate-counting used to quantify microorganisms may underestimate the actual number of bacteria as only cultivable and viable cells were detected on the agar plates used, thus possibly constituting only a part of the

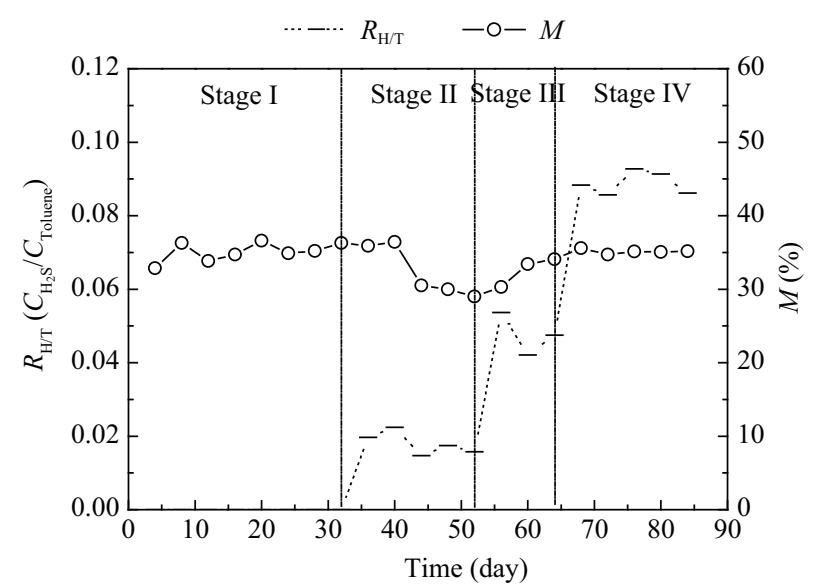

Fig. 4 Carbon dioxide conversion rate $(M)$ of toluene under different $R_{\mathrm{H} / \mathrm{T}}$ values. $M=C_{\mathrm{m}} / C_{\mathrm{t}} \times 100 \% ; R_{\mathrm{H} / \mathrm{T}}=C_{\mathrm{H}_{2} \mathrm{~S}} / C_{\text {Toluene }}$. 
total population present in the biofilters (Ho et al., 2008). The PCR-DGGE was used to generate genetic fingerprints to provide information on bacterial compositions including the culturable and nonculturable microbes in the bioreactor. The DGGE gel profile was also measured statistically by the Shannon index, which is commonly used to characterize species diversity in microbial communities.

Figure 5 shows the DGGE profiles of the bacterial communities in each stage. Lane "Original" shows community fingerprints of original inoculated bacteria isolated from a xylene-degrading bioreactor in our laboratory. Lanes I, II, III and IV present the bacterial community in Stages I, II, III and IV, respectively. The intensity of a band represents the relative abundance of the corresponding microbial species (Fang and Liu, 2002; Zhang and Fang, 2001). The corresponding Shannon indices are shown in Table 2. Because inoculated bacteria from a xylenedegrading bioreactor can also degrade toluene (Heider et al., 1998), the band patterns of inoculated bacteria were more complex in comparison with bands of Stage I. Nine intense bands were observed from Lane "Original", and its Shannon index was 2.49. Compared to Lane "Original", both band amount and Shannon index of Lane I declined slightly, with three remarkable bands and Shannon index of 2.44. Therefore, the bacterial diversity decreased in Stage I because toluene was the sole target compound. The

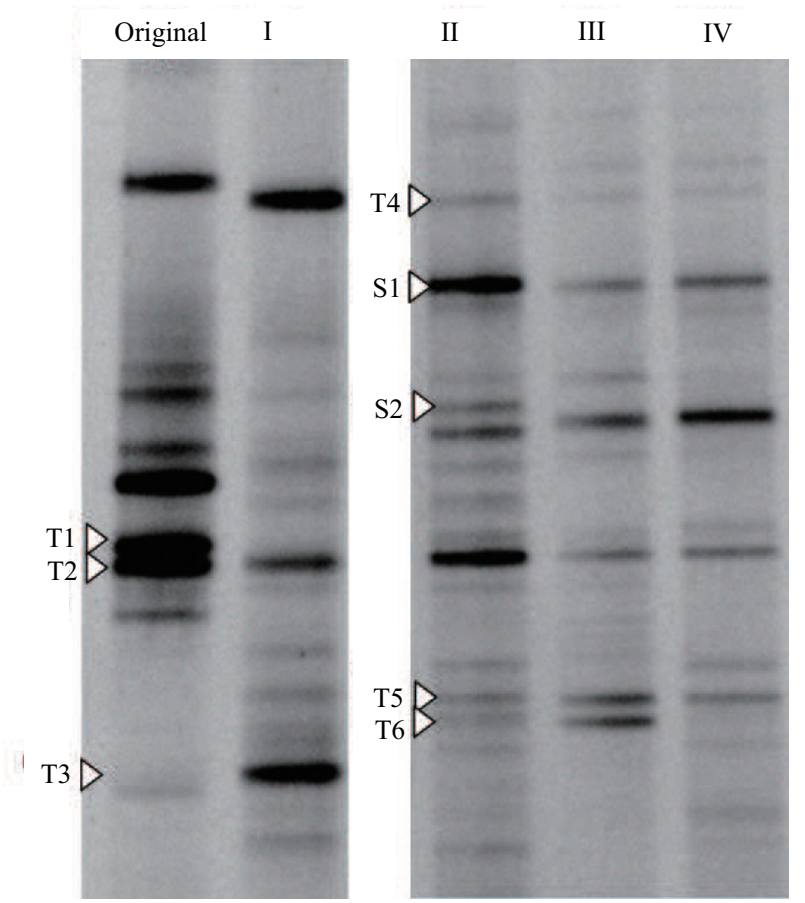

Fig. 5 DGGE profile of bacterial community of bioreactor. Original refers to inoculum. The number above each gel column stands for the stage of operation. T1-T6 are bacterial species related to toluene-degradation. $\mathrm{S} 1$ and $\mathrm{S} 2$ are the bacterial species related to $\mathrm{H}_{2} \mathrm{~S}$ degradation.

Table 2 Shannon diversity index for the DGGE gel patterns at individual stages

\begin{tabular}{llllll}
\hline Sampling points & Original & I & II & III & IV \\
\hline Shannon index value & 2.49 & 2.44 & 2.85 & 2.73 & 2.62 \\
\hline
\end{tabular}

DGGE profile showed that most of the band observed in inoculated bacteria disappeared in Stage I.

After adding $\mathrm{H}_{2} \mathrm{~S}, \mathrm{H}_{2} \mathrm{~S}$-degrading bacteria appeared and transformed $\mathrm{H}_{2} \mathrm{~S}$ into sulfate, which resulted in decreasing $\mathrm{pH}$ in the microbial carrier. Low $\mathrm{pH}$ was detrimental to the growth of toluene-degrading bacteria (Cox and Deshusses, 2002), which led to the immediate decrease of toluene removal efficiency. Thereafter, some toluene-degrading bacteria adapted to low $\mathrm{pH}$, which resulted in the gradual recovery of toluene removal efficiency. The addition of $\mathrm{H}_{2} \mathrm{~S}$ promoted an abundance of bacteria population in the bioreactor; therefore, band amount increased and new bands appeared in Lane II. The Shannon index of Lane II increased to 2.85 , and then dropped gradually with increasing $R_{\mathrm{H} / \mathrm{T}}$ in Stage III and Stage IV. However, little difference was observed from the band patterns and band amount besides the band intensity change in Lane III and Lane IV. The increasing $R_{\mathrm{H} / \mathrm{T}}$ did not influence diversity or the structure of bacterial community, although it evidently affected the concentration of functional bacteria. The amount of contaminant degraded was proportional to the number of bacteria produced in the bioreactor as kinetics of contamination is closely related to the kinetics of microbial growth.

\subsubsection{Dominant bacteria in the bioreactor}

To investigate pattern differences in detail, the discriminant bands of each Lane were extracted, reamplified, cloned, and sequenced. Seventeen sequences were recovered from DGGE bands. Their sequences were matched with the closest relative from the Genbank database. The relative quantity of bacteria was measured (Table 3) using Quantity One Software (Bio-Rad, USA), and was represented by the relative Qty. The strain name, nucleotide sequence similarity, and the relative quantity of dominant bacteria from each stage are listed in Table 3, in which six bacterial species (T1-T6) were related to toluenedegradation and two bacterial species ( $\mathrm{S} 1$ and $\mathrm{S} 2$ ) were related to $\mathrm{H}_{2} \mathrm{~S}$-degradation.

T1 was close to Gordonia sp. (98\%), and had microbial characteristics of butyl benzyl phthalate degradation (Chatterjee and Dutta, 2003). T2 was identified to Pseudomonas veronii $(100 \%)$, a long chain alkylphenol-degrading bacterium reported in previous work (Ajithkumar et al., 2003). T3 was assigned to Pseudomonas sp. strain PS+ (98\%), as a toluene-degrading bacterium (Mattison and Harayama, 2001). T4 was related to Hydrogenophaga sp. (99\%), which was a toluene-degrading bacterial strain (Fahy et al., 2008; Fries et al., 1997). T5 had a similarity of 99\% with Clostridium populeti, and was assigned to a methoxylated aromatic compound-degrading bacterium, which had sulfide tolerant characteristics (Lomans et al., 2001). Belonging to Bacteroides sp. (100\%), band T6 used to be detected from the bioreactor for the removal of benzene, toluene, ethylbenzene, and xylenes (BTEX), especially in the reactor containing polyurethane foam (Langenhoff et al., 1997; Oliveira et al., 2009). The S1 and S2 were similar to Pseudomonas sp. strain do-1 (100\%) and Dysgonomonas wimpennyi (98\%), respectively. 
Table 3 Relative Qty of dominant bacteria at individual stages

\begin{tabular}{|c|c|c|c|c|c|c|c|}
\hline \multirow[t]{2}{*}{ Band } & \multirow[t]{2}{*}{ Closest relatives } & \multirow{2}{*}{$\begin{array}{l}\text { Similarity } \\
(\%)\end{array}$} & \multicolumn{5}{|c|}{ Relative Qty of DGGE bands } \\
\hline & & & Original & Stage I & Stage II & Stage III & Stage IV \\
\hline $\mathrm{T} 1$ & Gordonia sp. & 98 & 13.25 & 1.95 & 2.92 & 2.5 & 3.06 \\
\hline $\mathrm{T} 2$ & Pseudomonas veronii & 100 & 14 & 5.51 & 6.51 & 3.88 & 3.76 \\
\hline $\mathrm{T} 3$ & Pseudomonas sp. strain PS+ & 98 & 4.38 & 11.62 & - & - & - \\
\hline $\mathrm{T} 4$ & Hydrogenophaga $\mathrm{sp}$ & 99 & - & 11.62 & 3.78 & 1.46 & 1.58 \\
\hline T5 & Clostridium populeti & 99 & - & 4.24 & 2.67 & 4.62 & 5.33 \\
\hline T6 & Bacteroides sp & 100 & - & 1.72 & 2.12 & 3.33 & 1.04 \\
\hline S1 & Pseudomonas sp. strain do- 1 & 100 & - & - & 8.78 & 4.79 & 4.99 \\
\hline S2 & Dysgonomonas wimpennyi & 98 & - & - & 3.12 & 6.23 & 6.36 \\
\hline
\end{tabular}

Pseudomonas sp. strain do-1 was reported as a hydrogen sulfide-removing bacterium isolated from soil (Honma and Akino, 1998), while Dysgonomonas wimpennyi was found in the system of sulphate-reducing consortium (Boothman et al., 2006).

Emergence of $\mathrm{T} 2$ in the inoculated microbial community indicated that toluene-degrading bacteria existed in the bioreactor at the beginning of operation. In Stage I, in which toluene was fed into the bioreactor as the sole target compound, another two functional bacteria (T3 and T4) with high relative Qty of 11.62 appeared as the dominant toluene-degrading bacteria. However, T3 could not be detected during Stage II to Stage IV. The relative Qty of $\mathrm{T} 4$ declined gradually with $\mathrm{H}_{2} \mathrm{~S}$ addition. In Stage IV, T4 was not the dominant bacteria. Another bacterium related to toluene-degradation, T5, emerged in Stage I and existed throughout the four stages. The relative Qty of $\mathrm{T} 5$ decreased in the presence of $\mathrm{H}_{2} \mathrm{~S}$, and then increased gradually. In Stage IV, T5 became the dominant toluenedegrading bacteria with a relative Qty of 5.33. The highest relative Qty (3.33) of T6 was discovered in the Stage III, and decreased to 1.04 in the Stage IV.

Two dominant sulfide-removing bacteria, S1 and S2, were observed in Stage II. After this, the relative Qty of S1 decreased from 8.78 (Stage II) to 4.99 (Stage IV), but the relative Qty of S2 increased from 3.12 (Stage II) to 6.36 (Stage IV) with the increase of $R_{\mathrm{H} / \mathrm{T}}$.

Cloning and sequencing of the selected predominant DGGE bands showed that six functional bacteria were detected in the bioreactor, including four bacterial species (T2, T4, T6 and T6) related to toluene-degradation and two bacterial species ( $\mathrm{S} 1$ and $\mathrm{S} 2$ ) related to $\mathrm{H}_{2} \mathrm{~S}$-degradation. Based on the above results, multiple functional bacteria could effectively remove toluene, $\mathrm{H}_{2} \mathrm{~S}$ and their corresponding metabolites. This suggests that a bacterial community consisting of different types of bacteria had a capacity to adapt to changes in gas composition and concentration.

\section{Conclusions}

Results in this study demonstrated that toluene and $\mathrm{H}_{2} \mathrm{~S}$ could be removed simultaneously in a single bioreactor, with high removal efficiencies achieved for both $(86 \%$ for toluene and $91 \%$ for $\mathrm{H}_{2} \mathrm{~S}$ ). Compared to when toluene was the sole target compound, the removal efficiency of toluene decreased immediately after adding $\mathrm{H}_{2} \mathrm{~S}$. After 20 days, removal efficiency rebounded and began to recover gradually. The elimination capacity of toluene increased with increasing inlet loading rates of toluene and $\mathrm{H}_{2} \mathrm{~S}$.

The dominant microbial community in the bioreactor played a crucial role in enhancing removal efficiency and elimination capacity. However, the dominant microbial community was interrelated with pollutant composition in the off-gases. Adding $\mathrm{H}_{2} \mathrm{~S}$ led to the growth of $\mathrm{H}_{2} \mathrm{~S}$-degrading bacteria and change of microenvironment for microbial growth, which resulted in the evolution of dominant microorganisms in the bioreactor. The community structure changed after $\mathrm{H}_{2} \mathrm{~S}$ addition. The dominant toluene-degrading bacteria changed from adapting neutral-pH species (Pseudomonas sp. strain PS+ and Hydrogenophaga sp.) to tolerating acidic-pH species (Clostridium populeti).

\section{Acknowledgments}

This work was supported by the National Natural Science Foundation of China (No. 50921064)

\section{References}

APHA (American Public Health Association/American Water Works Association /Water Environment Federation), 1998. Standard Methods for the Examination of Water and Wastewater (20th ed.). Washington DC, USA.

Ajithkumar B, Ajithkumar V P, Iriye R, 2003. Degradation of 4amylphenol and 4-hexylphenol by a new activated sludge isolate of Pseudomonas veronii and proposal for a new subspecies status. Research in Microbiology, 154(1): 1723.

Auria R, Frere G, Morales M, Acuma M E, Revah S, 2000. Influence of mixing and water addition on the removal rate of toluene vapors in a biofilter. Biotechnology and Bioengineering, 68(4): 448-455.

Boothman C, Hockin S, Holmes D, Gadd G, Lloyd J, 2006. Molecular analysis of a sulphate-reducing consortium used to treat metal-containing effluents. BioMetals, 19(6): 601609.

Chatterjee S, Dutta T K, 2003. Metabolism of butyl benzyl phthalate by gordonia sp. strain mtcc 4818. Biochemical and Biophysical Research Communications, 309(1): 36-43.

Cox H H J, Deshusses M A, 2002. Co-treatment of $\mathrm{H}_{2} \mathrm{~S}$ and toluene in a biotrickling filter. Chemical Engineering Journal, 87(1): 101-110.

Ding Y, Wu W, Han Z, Chen Y, 2008. Correlation of reactor performance and bacterial community composition during the removal of trimethylamine in three-stage biofilters. 
Biochemical Engineering Journal, 38(2): 248-258.

Dorado A D, Baquerizo G, Maestre J P, Gamisans X, Gabriel D, Lafuente J, 2008. Modeling of a bacterial and fungal biofilter applied to toluene abatement: Kinetic parameters estimation and model validation. Chemical Engineering Journal, 140(1-3): 52-61.

Duan H, Koe L C C, Yan R, Chen X, 2006. Biological treatment of $\mathrm{H}_{2} \mathrm{~S}$ using pellet activated carbon as a carrier of microorganisms in a biofilter. Water Research, 40(14): 2629-2636.

Fang H H P, Liu H, 2002. Effect of pH on hydrogen production from glucose by a mixed culture. Bioresource Technology, 82: 87-93.

Fahy A, Ball A S, Lethbridge G, Timmis K N, McGenity $\mathrm{T} \mathrm{J}$, 2008. Isolation of alkali-tolerant benzene-degrading bacteria from a contaminated aquifer. Letters in Applied Microbiology, 47(1): 60-66.

Fries M, Forney L, Tiedje J, 1997. Phenol- and toluene-degrading microbial populations from an aquifer in which successful trichloroethene co-metabolism occurred. Applied Environmental Microbiology, 63(4): 1523-1530.

Groenestijn J W van, Kraakman N J R, 2005. Recent developments in biological waste gas purification in Europe. Chemical Engineering Journal, 113: 85-91.

Heider J, Spormann A M, Beller H R, Widdel F, 1998. Anaerobic bacterial metabolism of hydrocarbons. FEMS Microbiology Reviews, 22(5): 459-473.

Ho K L, Chung Y C, Tseng C P, 2008. Continuous deodorization and bacterial community analysis of a biofilter treating nitrogen-containing gases from swine waste storage pits. Bioresource Technology, 99(8): 2757-2765.

Honma T, Akino T, 1998. Isolation and characterization of a hydrogen sulfide-removing bacterium, Pseudomonas sp. strain do-1. Bioscience, Biotechnology, and Biochemistry, 62(9): 1684-1687.

Islander R L, Devinny J S, Maansfield F, Postyn A, Shih H, 1991. Microbial ecology of crown corrosion in sewers. Journal of Environmental Engineering, 117(6): 751-770.

Jenkin M E, Watson L A, Utembe S R, Shallcross D E, 2008. A common representative intermediates (cri) mechanism for VOC degradation. Part 1: Gas phase mechanism development. Atmospheric Environment, 42(31): 7185-7195.

Langenhoff A A M, Nijenhuis I, Tan N C G, Briglia M, Zehnder A J B, Schraa G, 1997. Characterisation of a manganesereducing, toluene-degrading enrichment culture. FEMS Microbiology Ecology, 24(2): 113-125.

Liang J, Chiaw L K C, Ning X, 2007. Application of biological activated carbon as a low $\mathrm{pH}$ biofilter medium for gas mixture treatment. Biotechnology and Bioengineering, 96(6): $1092-1100$.
Lomans B P, Leijdekkers P, Wesselink J J, Bakkes P, Pol A, van der Drift C et al., 2001. Obligate sulfide-dependent degradation of methoxylated aromatic compounds and formation of methanethiol and dimethyl sulfide by a freshwater sediment isolate, Parasporobacterium paucivorans gen. Nov., sp. Nov. Applied Environmantal Microbiology, 67(9): 40174023.

Mattison R G, Harayama S, 2001. The predatory soil flagellate Heteromita globosa stimulates toluene biodegradation by a Pseudomonas sp. FEMS Microbiology Letters, 194(1): 3945.

Morales M, Hernandez S, Cornabe T, Revah S, Auria R, 2003. Effect of drying on biofilter performance: Modeling and experimental approach. Environmental Science and Technology, 37(5): 985-992.

Morgan-Sagastume J M, Noyola A, 2006. Hydrogen sulfide removal by compost biofiltration: Effect of mixing the filter media on operational factors. Bioresource Technology, 97(13): 1546-1553.

Møller S, Pedersen A R, Poulsen L K, Arvin E, Molin S, 1996. Activity and three-dimensional distribution of toluenedegrading Pseudomonas putida in a multispecies biofilm assessed by quantitative in situ hybridization and scanning confocal laser microscopy. Applied and Environmental Microbiology, 62(12): 4632-4640.

Oliveira L L, Duarte I C S, Sakamoto I K, Amancio Varesche M $\mathrm{B}, 2009$. Influence of support material on the immobilization of biomass for the degradation of linear alkylbenzene sulfonate in anaerobic reactors. Journal of Environmental Management, 90(1): 1261-1268.

Pedersen A R, Arvin E, 1997. Toluene removal in a biofilm reactor for waste gas treatment. Water Science and Technology, 36(1): 69-76.

Sanchez O, Gasol J M, Massana R, Mas J, Pedros-Alio C, 2007. Comparison of different denaturing gradient gel electrophoresis primer sets for the study of marine bacterioplankton communities. Applied Environmantal Microbiology, 73(18): 5962-5967.

Sercu B, Boon N, Verstraete W, Van Langenhove H, 2006. $\mathrm{H}_{2} \mathrm{~S}$ degradation is reflected by both the activity and composition of the microbial community in a compost biofilter. Applied Microbiology and Biotechnology, 72(5): 1090-1098.

Sun Y, Quan X, Chen J, Yang F, Xue D, Liu Y et al., 2002. Toluene vapour degradation and microbial community in biofilter at various moisture content. Process Biochemistry, 38(1): 109-113.

Zhang T, Fang H H, 2001. Phylogenetic diversity of a SRB-rich marine biofilm. Applied Microbiology Biotechnology, 57: 437-440. 